Archaeological Journal

\title{
On the First Passage of the Thames by Aulus Plautius
}

\section{F. C. J. Spurrell}

To cite this article: F. C. J. Spurrell (1890) On the First Passage of the Thames by Aulus Plautius, Archaeological Journal, 47:1, 43-47, DOI: 10.1080/00665983.1890.10852408

To link to this article: http://dx.doi.org/10.1080/00665983.1890.10852408

曲 Published online: 15 Jul 2014.

Submit your article to this journal $\pi$

Q View related articles $₫$ 


\section{ON THE FIRST PASSAGE OF THE THAMES BY AULUS PI.AUTIUS. ${ }^{1}$}

BJ F. C. J. SPURRELL.

In examining the movement of Aulus Plautius with respect to his passage of the River Thames at a particular spot, described by Dion Cassius lx $\S 19-23$, as marked by certain physical features, it is necessary to follow his movements from the beginning of the expedition in order to determine whether he crossed from the North or the South. All previous writers agree and I also that Plautius started his expedition from Boulogne. ${ }^{2}$ It consisted of four legions and a carefully prepared equipage, including some elephants. There was about 50,000 men divided into three parts, which we may call corps d'armee.

From the point of departure the Expedition went West ; now westward from Boulogne is along the south coast of Sussex and Hants. The soldiers did not like this expedition, even before it started, and doubtless they remembered the failure of Caligula's attempt to land, and the painful experience of tossing about and severe seasickness to which that commander and his forces apparently succumbed. On the occasion of Plautius' attempt, being further out in the channel, the great seas

\footnotetext{
${ }^{1}$ Read at the Monthly Meeting of the Institute, November, 1888.

2 "The chief papers on the subject of these remarks are those by Dr. Guest in the Archæological Journal, Vol, xiii, and Sir G. Airy's papers in the Athenreum, Jan. 28th, 1860, reprinted with an added map in a collection called 'Essays on the Roman Invasions of Britain,' and lastly an article in Nature, April 14, 1886 . It might be tedious to recapitulate fully the opinions of these writers, so I shall only refer to these occasionally. Dion's account is given in the Archæological Journal, xxiii, and by Petrie and Sharp, and though it
}

need not be repeated, for all employ the same words in translation, there is considerable difference in the modes of explanation given by Dr. Guest and Sir G. Airy, and I find, in looking carefully at the exact sequence of events mentioned by Dion, that there is room for a still different view."

${ }^{3}$ Guest makes the expedition go northward to Richboro', to Dover, and northwest to (Lymp)ne. Airy makes it go due north to Southend-on-the-Thumes, but I regard the star as my guide from Boulogne as a centre. 
and tempestuous weather drove the ships back to port, and so disheartened the men as to threaten the success of the affair, had they not been re-assured and their commander assisted by a kindly star, which, like them, westward sailing, cheered them on. It is not stated where the landing was effected, but that the enemy took to the marshes and woods instead of coming to an engagement. It may have been, as I think it was, therefore, that they landed somewhere in the neighbourhood of Porchester or in the Solent, this being the most likely place for reaching the first district named by Dion. ${ }^{1}$

Plautius after some time, having with difficulty brought on an engagement, defeated first Caractacus and then Togodumnus. Caractacus was ruler of the Midlands; he was the head of many tribes and kings, and Togodumnus was his ally. Bericus, when he sought the aid of Claudius, desired to overcome Caractacus as the chief of his enemies; this, it appears to me, explains why Plautius made for the nearest port to Caractacus' headquarters, among the Catuvellauni. No places are indicated by Dion as the sites of the first two battles, but the Boduni, who were subject to the Catuvellauni, had the honour of supporting a Roman Garrison. The Boduni have been generally considered as the same tribe as the Dobuni of Ptolemy and they lived. around Corinuim or Cirencester ; if, therefore, Plautius went for that place first it would explain his having no rivers to cross, or at least, as we find, none worth recording. Having passed round by the Cotswolds, or, at all events by the head waters of the Thames river, the army went eastward triumphantly through the Catuvellaunian state which lay north of the Thames, perhaps somewhat in the line of the Akeman Street as given by Guest, until it came to a "certain" river, which the barbarians supposed could not be crossed without a bridge. ${ }^{2}$ If this was not the Colne it was the Lea, being, as I suppose, the only river which could have caused any trouble along the line of

${ }^{1}$ Dr. Guest makes the expedition land
at three distant places. But Dion does
not mention this, he only says it was
divided into three, but it clearly is implied
that the landing was at one time and
place, no opposition being offered.
${ }^{2}$ Some older writers, with Horsley,
make it the Severn. Ward thinks it was a river neither so large nor so far west. Guest says it was the Thames at Wallingford, but the Thames is first mentioned after this battle, and, as the engagement took place not far from the estuary, it could not have occurred at Wallingford. Airy's account I cannot follow at all with Dion. 
march suggested by me. The battle was desperate and lasted two days. As the borders of Caractacus' State, that of the Catuvellauni, and the borders of 'Togodumnus' State that of the Trinobantes, was at the Lea or somewhere near it, it is easily understood why the defeated Britons should make a stand at so propitious a spot. The Lea below Rye House presented at that time just the conditions which the description of the battle requires for its comprehension. At this battle Togodumnus was slain and the Britons retreated to the Thames, which they crossed. Having come now to the point of special interest with me I give the two translations which, perhaps, have the greatest value in the understanding of the matter, thus,

Petrie and Sharp:- "The Britons retreating to the River Thames where it disembogues itself into the ocean and becomes an estuary at high tide, and easily passing it, as they were well acquainted with those parts which were firm and fordable, the Romans pursued them, \& c.

Dr. Guest.- "The Britons having withdrawn themselves thence to the River Thames whence it empties itself into the ocean, and at flow of tide forms a lake, \&c."

The lake theory is in my opinion a stretch of the verb $\lambda_{\iota \mu a ́}{ }^{\prime} \omega$, as it equally well means forms marshes as forms a lake, in which case it would be a salt lake. I therefore prefer to say, forms an estuary as commonly understood, before the river joined the sea. At the time the Romans came the river valley was a fenny, marshy district, permeated by fresh streams, for a distance many miles further down than at the present day, and at that time never overwhelmed by sea-water. The marshes were covered with large and old trees, in fact, it was firm ground. The meads were inhabited for some distance below Gravesend and Tilbury. As the river flowed only in one direction in this district it was very different from the present one. There were no banks, it was much narrower and shallower, and liable to be obstructed by gravel and sandbanks. Sunken trees (snags) and shallows abounded, which facilitated the construction of conveniences for traversing the lowlands, thus making it easily passable to those knowing the way. It may assist the comprehension of my meaning if we fancy twenty miles or so of the Thames above London, without the embankments 
as now, deferred to the twenty miles below it, I mean as to physical conditions, not as to direction of How. Then much of the theories of Airy and Guest would be applicable to the district about Gravesend or lower down. Considering the abundant Roman remains about East Tilbury and Higham-the course of ancient roads and the evidence of subsequent history-it is quite possible that Plautius crossed there or thereabout. The word

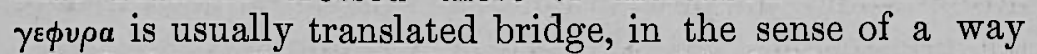
raised clear above the water. Yet this bridge may not have been of such a kind; the expression that "the Romans passed by means of fords and a bridge, a little higher up," does not necessarily imply a bridge with arches ; at the most, I think, it might have been a bridge on piles. Yet even this is not necessary. The English word bridge had other meanings than that confined to arch or bow, as I have before remarked, and it appears

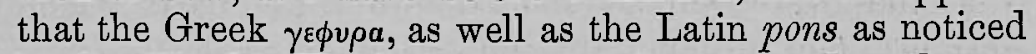
by Dr. Ward, (Horsley) may sometimes be allowed considerable and similar varieties of meaning.

When the Britons crossed the Romans pursued them, and at this point failed to overtake them, but the Keltoi swimming over again (as on the Lea passim), and others passing by means of a bridge, a little higher up, they attacked the Britons on every side and cut off many of them; but, rashly pressing on the remainder, they (Romans) wandered into the pathless marshes and lost many of their own soldiers. Having got across the River, ${ }^{2}$ Plautius secured his present possessions and sent for Claudius. Plautius settled for a time on the south side of the Thames. ${ }^{3}$ I cannot point to any spot where he

${ }^{1}$ Dr. Ward quotes a passage from Herodian II., 47, thus "He took care, in the first place, to lay bridges through the fenny grounds that the soldiers, marching in safety, might readily pass them and might stand firmly upon a solid bottom when they fought, for many places of Britain upon the recess of the tide become fenny, which the barbarian are accustomed to swim over or wade through up to the hips."

${ }^{2}$ Dr. Guest does not consider that the Romans crossed the River Thames now, but that Plautius encamped on the present site of London to wait for Claudius. He says "When they" (the Romans) "stated that they crossed the Thames they merely meant that they crossed the northern area of the Great Lake which spread out its waters before them on either hand," that is, they crossed the Lea River, and he feels "driven to place "this crossing on the fords of the Watling Street in the neighbourhood of Stratford."

${ }^{3}$ He must have got across the river into Kent or Surrey, because Claudius and he had to re-cross the river to get to Camalodunum. Airy places Plautius' quarters at Keston, but Keston is not on the Thames, nor do we know where Noviomagus was. 
encamped; it is not likely that it was in one spot only that forty or fifty thousand men encamped, besides, the shore, or river side and country of North Kent has always been a highly-civilized district, and civilization levels all asperities and greatly tends to remove all signs of war. In this district sundry vestiges of camps, which I have known have been finally obliterated within my memory. When. Claudius arrived he found Plautius on the south of the Thames, in Kent as I think, and this is the more likely since Claudius, during his visit, was able to accomplish so much in so short a time. He landed and joined Plautius, fought a battle in crossing the Thames northward, destroyed Camulodunum, subjugated several other places, and taking leave of Britain embarked, all within the space of sixteen days, of which he could hardly have spent a week in Essex. 